\title{
Bioavailability of Palm Oil Carotenoids Consumed from Different Foods
}

\author{
Fabrice F. D. Dongho ${ }^{1}$, Mathieu Ndomou ${ }^{1}$, Annie R. N. Ngono $^{1}$, Adélaïde M. Demasse ${ }^{1}$, Florian J. Schweigert ${ }^{2}$ \\ $\&$ Inocent Gouado ${ }^{1}$ \\ ${ }^{1}$ Department of Biochemistry, Faculty of Science, University of Douala, P.O. Box 24157 Douala, Cameroon \\ ${ }^{2}$ Institute of Nutritional Science, University of Potsdam, Arthur-Scheunert-Allee 114-116, 14558 \\ Bergholz-Rehbrücke, Germany \\ Correspondence: Mathieu Ndomou, Department of Biochemistry, Faculty of Science, University of Douala, P.O. \\ Box 24157, Douala, Cameroon. Tel: 237-679-807-381. E-mail: nmathieu2009@yahoo.fr
}

Received: March 6, 2017

Accepted: March 30, 2017 Online Published: April 24, 2017

doi:10.5539/jfr.v6n3p48

URL: https://doi.org/10.5539/jfr.v6n3p48

\begin{abstract}
Crude palm oil (CPO), an ingredient with a high content in provitamins A, is usually consumed associated with foods that could affect carotenoids metabolism. This work aimed to evaluate the influence of foodstuffs prepared with the incorporation of CPO on carotenoids absorption. Thus, we studied carotenoids bioavailability in Cameroonian local meals based on CPO and three different foodstuffs: maize (Zea mais), cassava (Manihot esculente) or black eyed peas (Vigna unguiculata). Modified 'yellow sauce' prepared mainly with CPO was used as control meal. Eleven healthy volunteers with age range between 20-30 year and similar body mass index were submitted to the study. A total of four interventions (i.e., meal ingestion) were performed every six days. After meal ingestion blood samples were collected at $0,2,4$ and $6 \mathrm{~h}$, and carotenoids content were analyzed by HPLC. Results showed that control meal had the highest carotenoids absorption $(0.479 \pm 0.063 \mu \mathrm{g} . \mathrm{h} / \mathrm{ml}$.), followed by maize $(0.329 \pm 0.115 \mu \mathrm{g} . \mathrm{h} / \mathrm{ml})$ and cassava $(0.141 \pm 0.075 \mu \mathrm{g} . \mathrm{h} / \mathrm{ml})$ cakes. Food based on black eyed peas incorporated with CPO showed the smallest increase in blood carotenoids $(0.053 \pm 0.062 \mu \mathrm{g} . \mathrm{h} / \mathrm{ml})$. Notably, CPO consumption leads to a short term significant increase of blood carotenoids $(\mathrm{p}<0.05)$ that declines over time. Our results suggest that the association of CPO with different foodstuffs significantly affects carotenoids bioavailability. This effect seems to be more important for leguminous, followed by tubers and cereals.
\end{abstract}

Keywords: crude palm oil, food composition, carotenoids, bioavailability

\section{Introduction}

Vitamin A is an essential nutrient that supports growth, development, immune function, and vision in humans. Vitamin A deficiency (VAD) is a major nutritional concern in poor societies, especially in lower income countries were it mainly affects preschool children and pregnant women (WHO, 2009; Gretchen et al., 2015). In Cameroon, recent data showed that VAD is a public health concern with $38.8 \%$ of children being affected (Ministry of public health in Cameroon, 2011). The main cause of VAD is, generally, non-accessibility to vitamin A or provitamins A-rich foods (Edem, 2009; Engle-Stone, Nankap, Ndjebayi, \& Kenneth, 2014). It is widely recognized that food technology could be applied to fight against VAD in a sustainable way, among others health issues (Grant, 2015; Strehl et al., 2015). In developing countries, these dietary approaches are very encouraging (Pignitter \& Somoza, 2012; Guangwen, 2013). Preformed vitamin A from animal products are not always available (less than 20\%) or accessible for people living in developing countries, while provitamin A carotenoids from certain plant products are generally more available (more than $80 \%$ ) and cheaper (Souganidis, Laillou, Leyvraz, \& Moench-Pfanner, 2013; Grant, 2015). This is the case of the crude palm oil (CPO) extracted from the pulp of Elaeis guineensis, which has traditionally been an important cooking oil in the diet of the populations living in or near CPO production regions (Choo \& Kalanithi, 2014).

CPO provides to organisms not only provitamins A, but also vitamin E (tocotrienol and tocopherol), energy, essential fatty acids, phytosterols and phosphatides. Indeed, it is the main known source of carotenoids (700 to $900 \mathrm{ppm}$ ), principally provitamins A (56\% of $\beta$-carotene and 35\% of $\alpha$-carotene) (Mukherjee \& Mitra, 2009; Owoyele \& Owolabi, 2014; Chuks et al., 2016; Dongho et al., 2017). Only $0.8 \times 10^{6}$ tons (1.6\% of world production) will be necessary to cover annual vitamin A needs of individuals at risk of VAD (Betty, 2012). 
Moreover, several authors reported that consumption of CPO has a positive impact on vitamin A individual statute (Strobel, Tinz, \& Biesalski, 2007; Edem, 2009; Manorama, 2014; Odia, Ofori, \& Maduk, 2015; Olaf et al., 2015; Zhu et al., 2015). Because CPO does not have any plant matrix and has lipid environment which are factors favorable to carotenoids absorption, it has a special place among vegetable sources of VA (Mukherjee \& Mitra, 2009; Owoyele \& Owolabi, 2014). Unfortunately, it is not consumed alone; it is usually associated with other foods which could affect metabolism of carotenoids (Borel et al., 2005).

Carotenoids are extremely apolar and their metabolism is closely linked to that of lipids (Eroglu \& Harisson, 2013; Kiokias, Proestos, \& Varzakas, 2016). The key of carotenoids metabolism is their absorption that differs from one food to another and from one individual to another. The major differences in carotenoids absorption are explained theoretically by several factors (Guangwen, 2010). Among these factors, the nature and the quantity of carotenoids consumed, the carotenoids and vitamin A status of the individual, genetic factors, nature of the matrix in which carotenoids are incorporated, and the presence of food nutrients which can affect absorption (Borel et al., 2005; Aggett, 2010), could be mentioned. In this sense, several authors reported the influence of the presence of lipids, digestive fibers and divalent cations on carotenoids absorption (Roodenburg et al., 2000; Riedl, Linseisen, Hoffmann, \& Wolfram, 1999; Biehler, Hoffmann, Krause, \& Bohn, 2011).

In Cameroon, a nutritional survey conducted in Douala town showed that CPO is used as cooking oil in $97 \%$ of households. Moreover, $87 \%$ of the population regularly consumes numerous foods prepared with the addition of $\mathrm{CPO}$, mainly based on foodstuffs like fruits, cereals, tubers and leguminous. Among these foods, one has maize (Zea mais), cassava (Manihot esculenta) and black eyed peas (Vigna unguiculata) cakes which are widely consumed by Cameroonian population.

Given that foodstuffs have different structures and composition, could have different effects on intestinal absorption of CPO carotenoids and, in consequence, on their bioavailability (Betty, 2012; Souganidis et al., 2013; Kiokias et al., 2016). Thus, the aim of the present work was to evaluate CPO carotenoids bioavailability in the aroused three foods respectively based on cereal, tuber, and leguminous, prepared with the incorporation of CPO. This selection relies not only on the high frequency of consumption of these foods by the population, but also on the similarities in their preparation methods, and in the fact that can be eaten alone. Modified 'yellow sauce' prepared with $\mathrm{CPO}$ was used as control food.

\section{Materials and Methods}

\subsection{Study Population}

Eleven young men volunteers aged between 20-30 years were retained for the study. They were non-smokers and did not take any medication or dietary supplements (Vitamins A and E, Carotenoids, Zinc and Iron) two weeks before or during the study period. The participants were in apparent healthy conditions according to disease history. The study began by an information campaign among postgraduate students of the Faculty of Science of the University of Douala to whom they were explained the objectives and protocol to follow. Volunteers who met criteria were sensitized on the objectives of the study during a three sessions seminar in which also learned to identify carotenoids containing local foods. A non-exhaustive list of such foods was given to each participant and they were asked not to eat them during the study period. They could only eat dishes chosen from a list of low carotenoids containing foods that they received. The study was approved by the national committee of ethics of Cameroon ( ${ }^{\circ}$ 2014/05/452/L/CNERSH/CP). Written informed consents were obtained from all participants within the study.

\subsection{Tests and Control Meals}

Tests meals consisted of maize, cassava, and black eyed peas cakes and control was a modified 'yellow sauce' (Figure 1). For maize and cassava cakes, white varieties were used instead of yellow varieties because they contain carotenoids compared to white varieties (FAO, 2012). Carotenoids content of dry seeds maize, cassava tubers, dry seeds of black eyed peas and of CPO used were firstly determined by photometry (using iCheck ${ }^{\mathrm{TM}}$ Carotene; BioAnalyt $\mathrm{GmbH}$, Germany) at $446 \mathrm{~nm}$ according to protocol used previously by Dongho, Ngono, Demasse, Schweigert and Gouado (2014). Carotenoids were not detected in maize, cassava and black eyed peas while their content in $\mathrm{CPO}$ was around $975 \mathrm{mg} / \mathrm{L}$. All meals were prepared on the eve of the intervention.

Test meals were prepared according to the data collected from housewives. Briefly, after obtaining paste from each foodstuff, salt and oil were added. After homogenization, this paste is packed and steamed. Thus, for the preparation of the maize cake (Figure 1A), about $4 \mathrm{~L}$ of water were added to $5 \mathrm{~kg}$ of dry maize flour obtained from maize seeds using a grinder (KENWOOD KMM005 MAJOR), and mixed until obtaining a homogenous paste. After adding salt and $500 \mathrm{~mL}$ of CPO the paste was mixed until complete absorption of the oil. For 
cassava cake preparation (Figure 1B), 5 tubers of cassava (about $5 \mathrm{~kg}$ ) were peeled off, washed, and soaked in $5 \mathrm{~L}$ water for 4 days. After draining, the tubers were ground in a mortar until obtaining a homogenous paste. This paste was salted and mixed with $500 \mathrm{~mL}$ of CPO. Once oil was totally absorbed, the paste was mixed and filled up with $1 \mathrm{~L}$ water until complete homogenization. Concerning black-eyed peas cake (Figure $1 \mathrm{C}$ ), $5 \mathrm{~kg}$ of dry seeds of black-eye peas were soaked in $5 \mathrm{~L}$ water for about 1 hour. Seeds were then washed in order to remove the white dandruff and were ground using a grinder (TECHWOOD TBLI360). The paste obtained was salted and mixed with $500 \mathrm{~mL} \mathrm{CPO}$. Then, the preparation was mixed a while and filled up to about $2 \mathrm{~L}$ with water until obtaining a homogeneous liquid. For each type of dish, about $300 \mathrm{~g}$ of paste were wrapped in banana leaves and steamed $\left(105^{\circ} \mathrm{C}\right)$ for $2 \mathrm{~h}$ using an aluminium cooking pot.

Control meal (Figure 1D) was prepared by modifying the protocol of 'yellow sauce' performed by local cookers. This type of sauce is generally prepared from CPO, an emulsifier (halite), salt and spices. In our study, in order to avoid influence of spices on carotenoids absorption, control sauce was prepared only with CPO, salt and halite. For this preparation, $300 \mathrm{~mL}$ of CPO were poured into $3 \mathrm{~L}$ water. Then, $15 \mathrm{~g}$ of sodium chloride were added to the solution which was later emulsified with halite and homogenized.

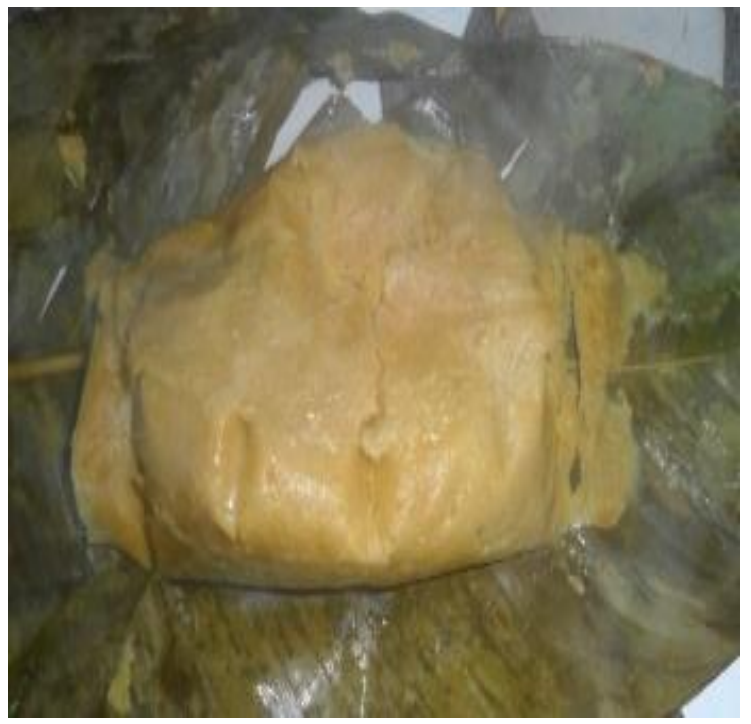

(A)

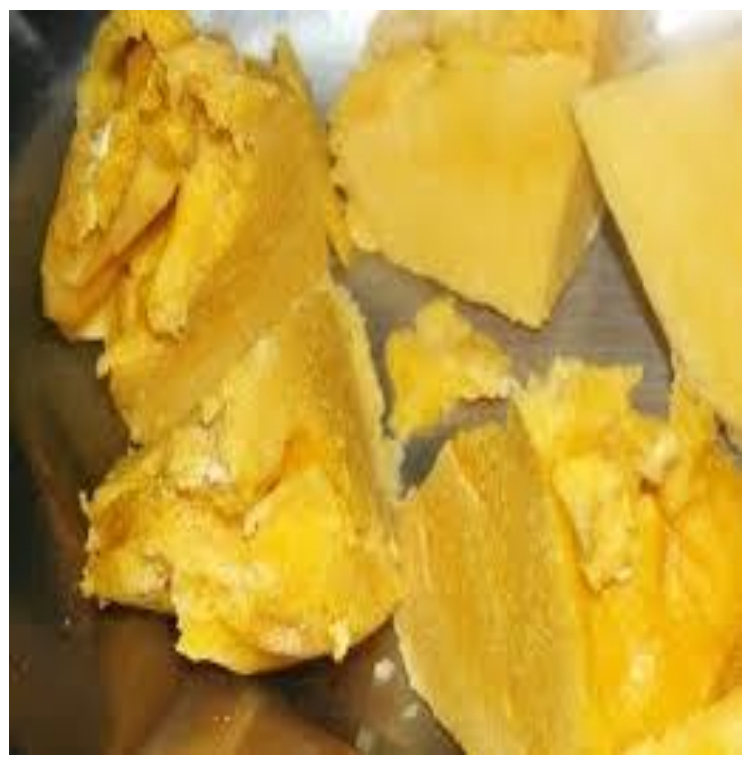

(C)

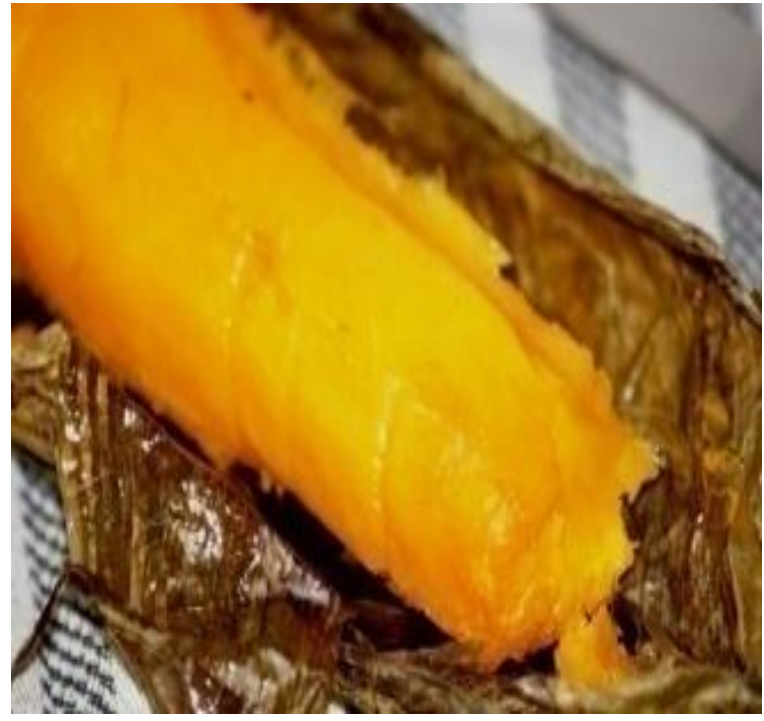

(B)

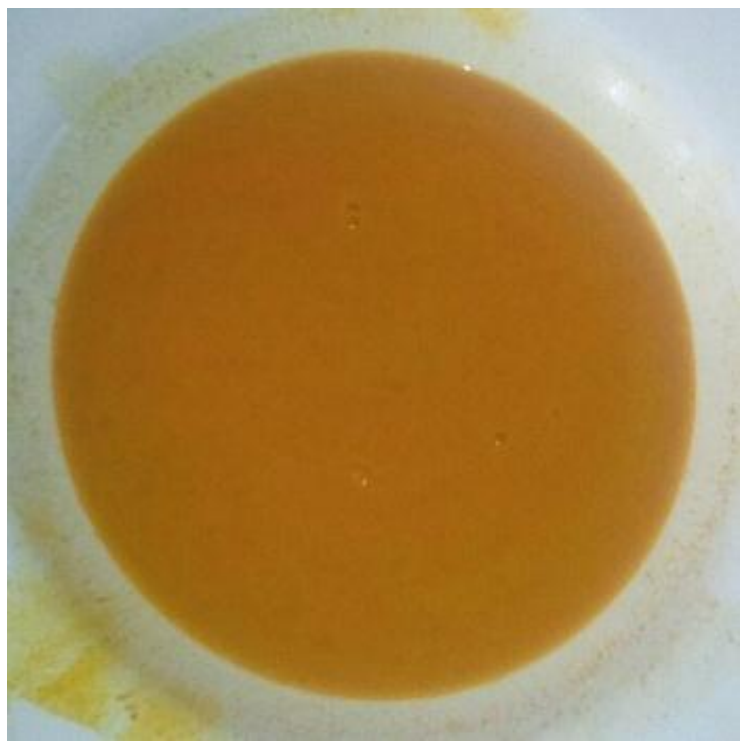

(D)

Figure 1. Photographs representing the different type of meals prepared for the present study: A) Maize cake; B)

Cassava cake; C) Black eyed peas cake; D): Yellow sauce 
Carotenoids content, proximal and mineral compositions of test and control meals are shown in table 1. Given that carotenoids were not detected in crops used in the present study, we considered that carotenoids present in different cooked meals came only from CPO.

Table 1. Carotenoids content, proximal and mineral compositions per $100 \mathrm{~g}$ of edible portion of test and control meals used in the study.

\begin{tabular}{|c|c|c|c|c|}
\hline & \multirow{2}{*}{$\begin{array}{l}\text { CONTROL MEAL } \\
\text { (yellow sauce) }\end{array}$} & \multicolumn{3}{|c|}{ TEST MEALS } \\
\hline & & Maize cake & Cassava cake & Black eyed peas cake \\
\hline \multicolumn{5}{|l|}{ CAROTENOIDS } \\
\hline Content (mg) & 10.53 & 2.6 & 2.78 & 2.67 \\
\hline Portion giving $10 \mathrm{mg}$ of carotenoids ( $\mathrm{g}$ ) & 95 & 385 & 360 & 375 \\
\hline \multicolumn{5}{|l|}{ PROXIMATE COMPOSITION (g) } \\
\hline Dried mater & 17.31 & 47.30 & 43.84 & 38.53 \\
\hline Proteins & 0.09 & 3.80 & 0.67 & 5.1 \\
\hline Lipids & 16.73 & 7.65 & 7.19 & 7.47 \\
\hline Digestive carbohydrates & 0.39 & 29.1 & 28.91 & 17.01 \\
\hline Dietary fibers & - & 5.45 & 6.27 & 7.41 \\
\hline Ashes & 0.10 & 1.30 & 0.80 & 1.54 \\
\hline \multicolumn{5}{|l|}{ MINERAL COMPOSITION (mg) } \\
\hline Calcium & 3.42 & 27.90 & 66.7 & 77.9 \\
\hline Magnesium & 1.61 & 27.80 & 50.30 & 45.87 \\
\hline Iron & 0.085 & 0.93 & 2.20 & 3.98 \\
\hline Zinc & - & 0.98 & 1.68 & 1.02 \\
\hline Manganese & - & 0.18 & 0.81 & 0.73 \\
\hline Copper & - & 0.65 & 0.59 & 0.79 \\
\hline Potassium & 279.20 & 237.25 & 336.90 & 289.87 \\
\hline Sodium & 14.01 & 4.97 & 24.36 & 14.87 \\
\hline
\end{tabular}

\subsection{Intervention}

The study was divided in four periods of six days, five days for withdrawal of carotenoids foods and one day for meals ingestion experience (Figure 2).

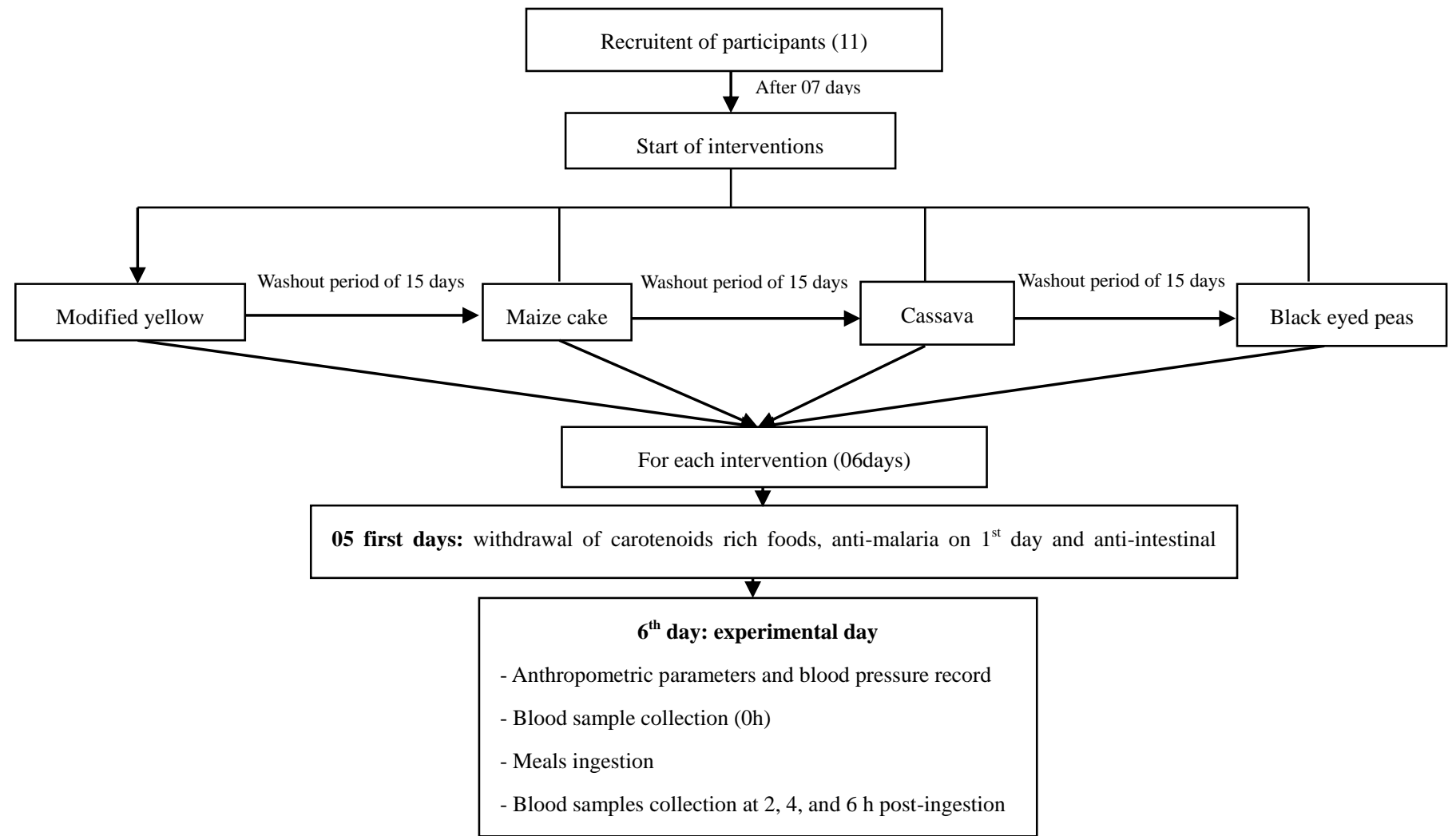

Figure 2. Intervention design 
Consecutive interventions were separated by a washout period of 15 days during which subjects return to their habitual diet. During the withdrawal period the subjects were treated with $500 \mathrm{mg}$ Sulfadoxine $+25 \mathrm{mg}$ Pyrimethamine on the second day and with $500 \mathrm{mg}$ of Mebendazole on the third day in order to dewormed them against malaria and intestinal worms.

On the experimental day, fasting subjects were received at the laboratory early in the morning. Anthropometric parameters (weight, height) and blood pressure were recorded and blood collected by venous puncture $(0 \mathrm{~h})$. Test and control meals providing $10 \mathrm{mg}$ of carotenoids were ingested by the volunteers (Table 1). Food was eaten in the presence of at least one investigator to prevent any irregularity. Blood samples were collected at 2, 4, and $6 \mathrm{~h}$ post-ingestion.

\subsection{Serum Preparation}

Serum was obtained by blood samples centrifugation $(5 \mathrm{~min}$ at $3000 \mathrm{rpm})$ and stored at $-80{ }^{\circ} \mathrm{C}$ in brown cryotubes until carotenoids analysis (lutein, zeaxanthin, $\beta$-cryptoxanthin, $\beta$-carotene, $\alpha$-carotene and lycopene). Experiments were conducted in dark to avoid carotenoids and retinol photo-degradation. Hemolyzed blood samples were discarded.

\subsection{Quantification of Serum Carotenoids, Retinol, A-Tocopherol and Triglycerides}

Separation and quantification of carotenoids (lutein, zeaxanthin, $\beta$-cryptoxanthin, $\alpha$-carotene, $\beta$-carotene and lycopene), retinol and $\alpha$-tocopherol, were performed by HPLC according to the method described by Schweigert, Klingner, Hurtienne, and Zunft (2003). Serum samples were unfrozen to ambient temperature $\left(25^{\circ} \mathrm{C}\right)$. In a test tube, $200 \mu \mathrm{L}$ of serum were added to $500 \mu \mathrm{L}$ of absolute ethanol containing $0.05 \%$ BHT in order to precipitate proteins. After homogenization in a vortex (MS2 minishaker, IKA, Janke and Kunkel, Staufen, Germany), $1 \mathrm{~mL}$ of $\mathrm{n}$-hexane was added to the test tube for carotenoids and vitamin extraction and stirred at $10 \mathrm{rpm}$ for $15 \mathrm{~min}$ using an agitator (Fröbel labor technik GmBH, Lindau, Type PR 50 L, Germany). Then, samples were centrifuged at $3000 \mathrm{rpm}$ during $5 \mathrm{~min}$ at $-5{ }^{\circ} \mathrm{C}$ and the n-hexane layer was transferred into another labeled tube. This procedure was repeated twice. The $\mathrm{n}$-hexane phase was then evaporated under nitrogen and the residue was resuspended in $200 \mu \mathrm{l}$ of acetonitrile and subjected to sonication for $30 \mathrm{~min}$ at $10^{\circ} \mathrm{C}$ (Bioblock Scientific 88169). A $60 \mu \mathrm{L}$ sample of the extract was then injected into the loop of the HPLC system. For separation and quantification of carotenoid compounds a C30 column $(5 \mu \mathrm{m}, 250 \times 4.6 \mathrm{~mm}$; YMC, Wilmington, USA) was used in line with a C18 pre-column (Luna, Phenomenex, Germany). The mobile phase consist of two solvent system: A) methanol (Roth Chemicals Germany):water (90:10 v:v, with $0.4 \mathrm{~g} / \mathrm{l}$ ammonium acetate in $\mathrm{H}_{2} \mathrm{O}$ ) and, B) methanol:methyl-tert-butyl-ether (Sigma Deisenhofen, Germany):water (8:90:2 v:v:v, with $0.1 \mathrm{~g} / \mathrm{l}$ ammonium acetate in $\mathrm{H}_{2} \mathrm{O}$ ) as described by Macias and Schweigert (2001). Lutein, zeaxanthin, $\beta$-cryptoxanthin, and lycopene standards were purchased from Hoffmann-La Roche (Switzerland). Alpha-carotene, $\beta$-carotene, $\alpha$-tocopherol and retinol were purchased from Sigma (Deisenhofen, Germany).

Serum triglycerides were measured by an enzymatic colorimetric method at $510 \mathrm{~nm}$ using a commercially available kit (SGM Italia, Italy

\subsection{Statistical Analysis}

Data were processed using the Microsoft Excel programme (version 2010). Statistical analyses were performed with Graph Pad Prism package version 5.00 (San Diego California USA). T-Student and one-way ANOVA (analysis of variance) tests were used for multiple comparisons with a significance level of $P<0.05$.

\section{Results}

In order to evaluate the influence of the food matrix on carotenoids absorption, the area under curve (AUC) of these parameters according to the time was calculated by trapezoidal approximation Molldrem, Li, Simon, \& Tanumihardjo, 2004). For each meal and for each blood parameter analysed, we evaluated the influence of the time after consumption of food on the blood concentration of the parameter. Each blood carotenoid (lutein, zeaxanthin, $\beta$-cryptoxanthin, $\beta$-carotene, $\alpha$-carotene and lycopene) were first analyzed separately and total carotenoids calculated. In order to evaluate the contribution of CPO for blood carotenoids and the influence of the food matrix on their absorption, we focused on $\beta$-carotene, $\alpha$-carotene and lycopene which are normally present in $\mathrm{CPO}$

\subsection{Characteristics of the Subjects before Each Intervention}

Body mass index and blood parameters (pressure and carotenoids, retinol, $\alpha$-tocopherol and triglycerides content) of all participants at time $\mathrm{t}_{0}$ (before each intervention) are shown in Table 2. Reference values of carotenoids are not yet established for Cameroonian population. But our values were closely related to those obtained on healthy 
subjects elsewhere by previous workers (Boonsiri, Pooart, Tangrassameeprasert, \& Hongsprabhas, 2007; Ribaya-Mercado, Maramag, Tengco, Blumberg, \& Solon, 2008; Valtuena, Breidenassel, Folle, \& González-Gross, 2011; Kiokias et al., 2016). Alpha-tocopherol values were lower than that of reference while other parameters fitted with their respective references (Gouado et al., 2005).

Table 2. Anthropometric and blood parameters of participants

\begin{tabular}{|c|c|c|c|c|c|}
\hline & \multirow{3}{*}{$\begin{array}{l}\text { REFERENCE } \\
\text { VALUES }\end{array}$} & \multicolumn{4}{|c|}{ INTERVENTIONS } \\
\hline & & \multirow{2}{*}{$\begin{array}{l}\text { CONTROL } \\
\text { MEAL } \\
\text { (yellow sauce) }\end{array}$} & \multicolumn{3}{|c|}{ TEST MEALS } \\
\hline & & & $\begin{array}{l}\text { Maize } \\
\text { cake }\end{array}$ & $\begin{array}{l}\text { Cassava } \\
\text { cake }\end{array}$ & $\begin{array}{l}\text { Black eyed } \\
\text { peas cake }\end{array}$ \\
\hline Age (year) & - & $26.00 \pm 2.00$ & $26.00 \pm 2.00$ & $26.00 \pm 2.00$ & $26.00 \pm 2.00$ \\
\hline BMI (kg/m²) & $18.50-24.90$ & $21.53 \pm 1.70$ & $20.35 \pm 1.91$ & $21.08 \pm 1.78$ & $21.29 \pm 1.77$ \\
\hline Blood pressure (mmHg) & $<140 / 90$ & $124 / 72 \pm 7 / 6$ & $118 / 74 \pm 9 / 8$ & $125 / 72 \pm 11 / 8$ & $124 / 73 \pm 2 / 7$ \\
\hline \multicolumn{6}{|l|}{ Carotenoids $(\mu \mathrm{g} / \mathrm{ml})$} \\
\hline Lutein & $\mathrm{NE}$ & $0.095 \pm 0.011$ & $0.089 \pm 0.017$ & $0.088 \pm 0.009$ & $0.113 \pm 0.018$ \\
\hline Zeaxanthin & $\mathrm{NE}$ & $0.019 \pm 0.001$ & $0.021 \pm 0.003$ & $0.017 \pm 0.002$ & $0.018 \pm 0.002$ \\
\hline$\beta$-cryptoxanthin & $\mathrm{NE}$ & $0.026 \pm 0.009$ & $0.027 \pm 0.017$ & $0.020 \pm 0.007$ & $0.030 \pm 0.006$ \\
\hline$\alpha$-carotene & $\mathrm{NE}$ & $0.190 \pm 0.064$ & $0.168 \pm 0.049$ & $0.180 \pm 0.074$ & $0.221 \pm 0.075$ \\
\hline$\beta$-carotene & $\mathrm{NE}$ & $0.368 \pm 0.189$ & $0.321 \pm 0.144$ & $0.355 \pm 0.189$ & $0.428 \pm 0.241$ \\
\hline Lycopene & $\mathrm{NE}$ & $0.105 \pm 0.025$ & $0.090 \pm 0.027$ & $0.095 \pm 0.025$ & $0.131 \pm 0.034$ \\
\hline Retinol $(\mu \mathrm{g} / \mathrm{ml})$ & $0.200-0.300$ & $0.259 \pm 0.036$ & $0.267 \pm 0.018$ & $0.244 \pm 0.055$ & $0.266 \pm 0.048$ \\
\hline$\alpha$-tocopherol $(\mu \mathrm{g} / \mathrm{ml})$ & $5.46-19.78$ & $4.86 \pm 0.58$ & $4.68 \pm 0.86$ & $4.64 \pm 0.91$ & $5.20 \pm 0.76$ \\
\hline Triglycerides (mg/dl) & $<195.00$ & $77.63 \pm 6.63$ & $77.31 \pm 7.14$ & $76.85 \pm 11.16$ & $78.72 \pm 4.90$ \\
\hline
\end{tabular}

NE: Reference values not yet established

\subsection{Effect of Studied Meals Intake on Blood Carotenoids}

\subsubsection{Individual Carotenoids}

Carotenoids blood levels as a function of time is shown at Table 3. For control and test meals, blood contents of lutein, zeaxanthin and $\beta$-cryptoxanthin significantly $(\mathrm{P}<0.0001)$ decreased with time. Meanwhile, $\alpha$ - and $\beta$-carotene contents increased significantly with time for control meal and maize cake. There is not significant change for cassava and black eyed peas cakes. Lycopene blood contents significantly $(\mathrm{P}<0.0001)$ increase for the control meal, but this increase was not observed for the test meals. 
Table 3. Changes in the blood levels of the carotenoids analysed according to meal as a function of time

\begin{tabular}{|c|c|c|c|c|c|}
\hline \multirow[t]{2}{*}{ PARAMETERS } & \multicolumn{4}{|c|}{ TIME AFTER CONSUMPTION OF MEAL (hour) } & \multirow[b]{2}{*}{$\mathbf{P}$} \\
\hline & $\mathbf{0}$ & 2 & 4 & 6 & \\
\hline \multicolumn{6}{|l|}{ LUTEIN $(\mu \mathrm{g} / \mathrm{ml})$} \\
\hline Control meal (yellow sauce) & $0.095 \pm 0.011^{\mathrm{a}}$ & $0.088 \pm 0.011^{\mathrm{b}}$ & $0.084 \pm 0.009^{\mathrm{c}}$ & $0.075 \pm 0.008^{\mathrm{d}}$ & $<0.0001$ \\
\hline \multicolumn{6}{|l|}{ Test meals } \\
\hline Maize cake & $0.089 \pm 0.017^{\mathrm{a}}$ & $0.084 \pm 0.018^{\mathrm{a}, \mathrm{b}}$ & $0.078 \pm 0.016^{\mathrm{b}, \mathrm{c}}$ & $0.073 \pm 0.018^{\mathrm{c}}$ & $<0.0001$ \\
\hline Cassava cake & $0.088 \pm 0.009^{\mathrm{a}}$ & $0.084 \pm 0.009^{\mathrm{b}}$ & $0.078 \pm 0.009^{\mathrm{c}}$ & $0.072 \pm 0.007^{\mathrm{d}}$ & $<0.0001$ \\
\hline Black eyed peas cake & $0.113 \pm 0.018^{\mathrm{a}}$ & $0.101 \pm 0.018^{\mathrm{b}}$ & $0.099 \pm 0.013^{\mathrm{b}, \mathrm{c}}$ & $0.082 \pm 0.015^{\mathrm{c}}$ & $<0.0001$ \\
\hline \multicolumn{6}{|l|}{ ZEAXANTHIN $(\boldsymbol{\mu g} / \mathrm{ml})$} \\
\hline Control meal (yellow sauce) & $0.019 \pm 0.001^{\mathrm{a}}$ & $0.016 \pm 0.002^{\mathrm{b}}$ & $0.015 \pm 0.001^{\mathrm{b}, \mathrm{c}}$ & $0.015 \pm 0.001^{\mathrm{c}}$ & $<0.0001$ \\
\hline \multicolumn{6}{|l|}{ Test meals } \\
\hline Maize cake & $0.021 \pm 0.003^{\mathrm{a}}$ & $0.017 \pm 0.004^{\mathrm{b}}$ & $0.017 \pm 0.003^{\mathrm{b}}$ & $0.016 \pm 0.003^{\mathrm{b}}$ & $<0.0001$ \\
\hline Cassava cake & $0.017 \pm 0.002^{\mathrm{a}}$ & $0.016 \pm 0.001^{\mathrm{a}, \mathrm{b}}$ & $0.014 \pm 0.001^{\mathrm{c}}$ & $0.012 \pm 0.009^{c}$ & $<0.0001$ \\
\hline Black eyed peas cake & $0.018 \pm 0.002^{\mathrm{a}}$ & $0.015 \pm 0.003^{\mathrm{b}}$ & $0.015 \pm 0.003^{\mathrm{b}}$ & $0.015 \pm 0.002^{\mathrm{b}}$ & $<0.0001$ \\
\hline \multicolumn{6}{|l|}{ B-CRYPTOXANTHIN $(\mu \mathrm{g} / \mathrm{ml})$} \\
\hline Control meal (yellow sauce) & $0.026 \pm 0.009^{\mathrm{a}}$ & $0.018 \pm 0.009^{\mathrm{b}}$ & $0.016 \pm 0.007^{\mathrm{c}}$ & $0.014 \pm 0.006^{\mathrm{c}}$ & $<0.0001$ \\
\hline \multicolumn{6}{|l|}{ Test meals } \\
\hline Maize cake & $0.027 \pm 0.017^{\mathrm{a}}$ & $0.020 \pm 0.012^{\mathrm{b}}$ & $0.018 \pm 0.012^{\mathrm{b}, \mathrm{c}}$ & $0.014 \pm 0.001^{\mathrm{c}}$ & $<0.0001$ \\
\hline Cassava cake & $0.020 \pm 0.007^{\mathrm{a}}$ & $0.016 \pm 0.009^{b}$ & $0.014 \pm 0.007^{\mathrm{b}, \mathrm{c}}$ & $0.012 \pm 0.005^{\mathrm{c}}$ & $<0.0001$ \\
\hline Black eyed peas cake & $0.030 \pm 0.006^{\mathrm{a}}$ & $0.020 \pm 0.006^{\mathrm{b}}$ & $0.016 \pm 0.004^{c}$ & $0.016 \pm 0.005^{\mathrm{c}}$ & $<0.0001$ \\
\hline \multicolumn{6}{|l|}{$\alpha$-CAROTENE $(\mu \mathrm{g} / \mathrm{ml})$} \\
\hline Control meal (yellow sauce) & $0.190 \pm 0.064^{\mathrm{a}}$ & $0.218 \pm 0.071^{\mathrm{b}}$ & $0.208 \pm 0.075^{\mathrm{b}, \mathrm{c}}$ & $0.198 \pm 0.066^{\mathrm{a}, \mathrm{c}}$ & 0.0005 \\
\hline \multicolumn{6}{|l|}{ Test meals } \\
\hline Maize cake & $0.168 \pm 0.049^{\mathrm{a}}$ & $0.170 \pm 0.058^{\mathrm{a}, \mathrm{b}}$ & $0.176 \pm 0.067^{\mathrm{b}, \mathrm{c}}$ & $0.193 \pm 0.069^{c}$ & 0.0048 \\
\hline Cassava cake & $0.180 \pm 0.074^{\mathrm{a}}$ & $0.177 \pm 0.064^{\mathrm{a}}$ & $0.180 \pm 0.085^{\mathrm{a}}$ & $0.180 \pm 0.066^{\mathrm{a}}$ & $\mathrm{ns}$ \\
\hline Black eyed peas cake & $0.221 \pm 0.075^{\mathrm{a}}$ & $0.214 \pm 0.067^{\mathrm{a}}$ & $0.213 \pm 0.077^{\mathrm{a}}$ & $0.221 \pm 0.070^{\mathrm{a}}$ & ns \\
\hline \multicolumn{6}{|l|}{ B-CAROTENE $(\mu \mathrm{g} / \mathrm{ml})$} \\
\hline Control meal (yellow sauce) & $0.368 \pm 0.189^{\mathrm{a}}$ & $0.476 \pm 0.230^{\mathrm{b}}$ & $0.416 \pm 0.209^{c}$ & $0.387 \pm 0.213^{\mathrm{a}, \mathrm{c}}$ & $<0.0001$ \\
\hline \multicolumn{6}{|l|}{ Test meals } \\
\hline Maize cake & $0.321 \pm 0.144^{\mathrm{a}}$ & $0.342 \pm 0.163^{\mathrm{a}, \mathrm{b}}$ & $0.386 \pm 0.256^{\mathrm{b}}$ & $0.395 \pm 0.179^{\mathrm{a}}$ & 0.0068 \\
\hline Cassava cake & $0.355 \pm 0.189^{\mathrm{a}}$ & $0.371 \pm 0.192^{\mathrm{a}}$ & $0.393 \pm 0.262^{\mathrm{a}}$ & $0.380 \pm 0.218^{\mathrm{a}}$ & ns \\
\hline Black eyed peas cake & $0.428 \pm 0.241^{\mathrm{a}}$ & $0.438 \pm 0.210^{\mathrm{a}}$ & $0.443 \pm 0.240^{\mathrm{a}}$ & $0.449 \pm 0.238^{\mathrm{a}}$ & ns \\
\hline \multicolumn{6}{|l|}{ LYCOPENE ( $\mu \mathrm{g} / \mathrm{ml})$} \\
\hline Control meal (yellow sauce) & $0.105 \pm 0.025^{\mathrm{a}}$ & $0.120 \pm 0.032^{\mathrm{b}}$ & $0.111 \pm 0.035^{\mathrm{a}, \mathrm{c}}$ & $0.108 \pm 0.026^{\mathrm{a}, \mathrm{c}}$ & $<0.0001$ \\
\hline \multicolumn{6}{|l|}{ Test meals } \\
\hline Maize cake & $0.090 \pm 0.027^{\mathrm{a}}$ & $0.094 \pm 0.033^{\mathrm{a}}$ & $0.098 \pm 0.050^{\mathrm{a}}$ & $0.101 \pm 0.034^{\mathrm{a}}$ & $\mathrm{ns}$ \\
\hline Cassava cake & $0.095 \pm 0.025^{\mathrm{a}}$ & $0.096 \pm 0.024^{\mathrm{a}}$ & $0.099 \pm 0.034^{\mathrm{a}}$ & $0.095 \pm 0.030^{\mathrm{a}}$ & $\mathrm{ns}$ \\
\hline Black eyed peas cake & $0.131 \pm 0.034^{\mathrm{a}}$ & $0.135 \pm 0.033^{\mathrm{a}}$ & $0.136 \pm 0.039^{\mathrm{a}}$ & $0.126 \pm 0.032^{\mathrm{a}}$ & ns \\
\hline
\end{tabular}

The values are given as mean \pm standard deviation

For each parameter and for given meal, the values of the same line superscripted with the same letter are not significantly different at $\mathrm{P}<0.05$ ns: No significant difference at $\mathrm{P}<0.05$

\subsubsection{Total Carotenoids, Provitamins A and Non-Provitamins A}

Table 4 shows changes in blood total carotenoids (lutein + zeaxanthin $+\beta$-cryptoxanthin $+\beta$-carotene + $\alpha$-carotene + lycopene), total provitamins $A(\beta$-cryptoxanthin $+\beta$-carotene $+\alpha$-carotene $)$ and total non-provitamins A (lutein + zeaxanthin + lycopene) according to the type of meal and the time after consumption. Carotenoids values varied significantly $(\mathrm{P}<0.0001)$ with time for control meal while no significant changes were observed for the test meals. Moreover, for the control meal, carotenoids values significantly increased between 0 and 2 hours and decreased between 2 and 6 hours. It can be noted from data in Table 4 that, after maize cakes consumption, blood total carotenoids levels seems to increase as a function of time, but this tendency it is not significant. The opposite was observed after the ingestion of black eye peas cakes.

Total provitamins A blood levels significantly changed only after yellow control sauce and maize cake ingest. For yellow sauce, between 0 and 2 hours and between 2 and 6 hours these changes were the same as those of total carotenoids. In the case of maize cake consumption, total provitamins A blood levels only increased significantly between 0 and 6 hours $(\mathrm{P}=0.0098)$. For cassava and black eyed peas cakes, their blood levels did not change significantly after consumption of either test or control meals.

In general, non-provitamins A blood levels decreased between 0 and $6 \mathrm{~h}$ after meals intake, but this observation was not significant for maize cake. 
Table 4. Changes in blood levels of total carotenoids, provitamins A and non provitamins A analysed according to meal as a function of time

\begin{tabular}{|c|c|c|c|c|c|}
\hline \multirow[t]{2}{*}{ PARAMETRES } & \multicolumn{4}{|c|}{ TIME AFTER CONSUMPTION OF MEAL (hour) } & \multirow[b]{2}{*}{$\mathbf{P}$} \\
\hline & $\mathbf{0}$ & 2 & 4 & 6 & \\
\hline \multicolumn{6}{|l|}{ TOTAL CAROTENOIDS $(\mu \mathrm{g} / \mathrm{ml})$} \\
\hline Control meal (yellow sauce) & $0.801 \pm 0.276^{\mathrm{a}}$ & $0.937 \pm 0.332^{\mathrm{b}}$ & $0.850 \pm 0.312^{\mathrm{c}}$ & $0.799 \pm 0.302^{\mathrm{a}}$ & $<0.0001$ \\
\hline \multicolumn{6}{|l|}{ Test meals } \\
\hline Maize cake & $0.711 \pm 0.230^{\mathrm{a}}$ & $0.724 \pm 0.259^{\mathrm{a}}$ & $0.768 \pm 0.376^{\mathrm{a}}$ & $0.790 \pm 0.288^{\mathrm{a}}$ & ns \\
\hline Cassava cake & $0.752 \pm 0.277^{\mathrm{a}}$ & $0.758 \pm 0.272^{\mathrm{a}}$ & $0.778 \pm 0.375^{\mathrm{a}}$ & $0.752 \pm 0.295^{\mathrm{a}}$ & ns \\
\hline Black eyed peas cake & $0.940 \pm 0.332^{\mathrm{a}}$ & $0.925 \pm 0.285^{\mathrm{a}}$ & $0.922 \pm 0.333^{\mathrm{a}}$ & $0.908 \pm 0.324^{\mathrm{a}}$ & ns \\
\hline \multicolumn{6}{|l|}{ TOTAL PROVITAMINS A $(\mu \mathrm{g} / \mathrm{ml})$} \\
\hline Control meal (yellow sauce) & $0.583 \pm 0.260^{\mathrm{a}}$ & $0.713 \pm 0.306^{\mathrm{b}}$ & $0.640 \pm 0.283^{\mathrm{c}}$ & $0.611 \pm 0.277^{\mathrm{a}, \mathrm{c}}$ & $<0.0001$ \\
\hline \multicolumn{6}{|l|}{ Test meals } \\
\hline Maize cake & $0.516 \pm 0.205^{\mathrm{a}}$ & $0.532 \pm 0.228^{\mathrm{a}, \mathrm{b}}$ & $0.580 \pm 0.329^{\mathrm{a}, \mathrm{b}}$ & $0.602 \pm 0.254^{\mathrm{b}}$ & 0.0048 \\
\hline Cassava cake & $0.555 \pm 0.269^{\mathrm{a}}$ & $0.563 \pm 0.261^{\mathrm{a}}$ & $0.587 \pm 0.351^{\mathrm{a}}$ & $0.572 \pm 0.283^{\mathrm{a}}$ & ns \\
\hline Black eyed peas cake & $0.679 \pm 0.314^{\mathrm{a}}$ & $0.672 \pm 0.278^{\mathrm{a}}$ & $0.672 \pm 0.316^{\mathrm{a}}$ & $0.686 \pm 0.309^{\mathrm{a}}$ & ns \\
\hline \multicolumn{6}{|c|}{ TOTAL NON PROVITAMINS A $(\mu \mathrm{g} / \mathrm{ml})$} \\
\hline Control meal (yellow sauce) & $0.218 \pm 0.020^{\mathrm{a}}$ & $0.224 \pm 0.028^{\mathrm{a}, \mathrm{b}}$ & $0.210 \pm 0.033^{\mathrm{a}, \mathrm{b}, \mathrm{c}}$ & $0.184 \pm 0.045^{\mathrm{c}}$ & $<0.0001$ \\
\hline \multicolumn{6}{|l|}{ Test meals } \\
\hline Maize cake & $0.195 \pm 0.034^{\mathrm{a}}$ & $0.191 \pm 0.038^{\mathrm{a}}$ & $0.189 \pm 0.054^{\mathrm{a}}$ & $0.188 \pm 0.043^{\mathrm{a}}$ & ns \\
\hline Cassava cake & $0.197 \pm 0.027^{\mathrm{a}}$ & $0.195 \pm 0.026^{\mathrm{a}}$ & $0.192 \pm 0.036^{\mathrm{a}, \mathrm{b}, \mathrm{c}}$ & $0.180 \pm 0.032^{\mathrm{c}}$ & 0.0002 \\
\hline Black eyed peas cake & $0.261 \pm 0.023^{\mathrm{a}}$ & $0.252 \pm 0.028^{\mathrm{a}, \mathrm{b}}$ & $0.250 \pm 0.034^{\mathrm{a}, \mathrm{b}}$ & $0.222 \pm 0.024^{\mathrm{c}}$ & $<0.0001$ \\
\hline
\end{tabular}

The values are given as mean \pm standard deviation

For each parameter and for given meal, the values of the same line superscripted with the same letter are not significantly different at $\mathrm{P}<0.05$ ns: No significant difference at $\mathrm{P}<0.05$

\subsubsection{Crude Palm Oil Carotenoids}

Figure 3A shows that absorption of $\mathrm{CPO}$ carotenoids $(\beta$-carotene $+\alpha$-carotene + lycopene) varied significantly $(\mathrm{P}=0.0086)$ according to type of meal. In fact, absorption of control meal with an AUC of $0.479 \pm 0.063 \mu \mathrm{g} . \mathrm{h} / \mathrm{ml}$ is higher than that obtained with test meals. Among test meals, maize cake showed the best absorption with an AUC of $0.329 \pm 0.115 \mu \mathrm{g} . \mathrm{h} / \mathrm{ml}$ ( $69 \%$ of control meal's AUC) followed by cassava cake (30\% of control meal or $0.141 \pm 0.075 \mu \mathrm{g} . \mathrm{h} / \mathrm{ml}$ ). Black eyed peas cake showed the lowest (11\% of control meal's AUC or $0.053 \pm 0.062$ $\mu \mathrm{g} . \mathrm{h} / \mathrm{ml})$.

For CPO provitamins A ( $\beta$-carotene $+\alpha$-carotene), control meal showed an AUC of $0.433 \pm 0.052 \mu \mathrm{g} . \mathrm{h} / \mathrm{ml}$ against $0.292 \pm 0.013 \mu \mathrm{g} . \mathrm{h} / \mathrm{ml}$ ( $68 \%$ of control) for maize cake; $0.129 \pm 0.070 \mu \mathrm{g} . \mathrm{h} / \mathrm{ml}$ (30\% of control) for cassava cake and $0.046 \pm 0.044 \mu \mathrm{g} . \mathrm{h} / \mathrm{ml}$ (11\% of control) for black eyed peas cake (Figure 3B).

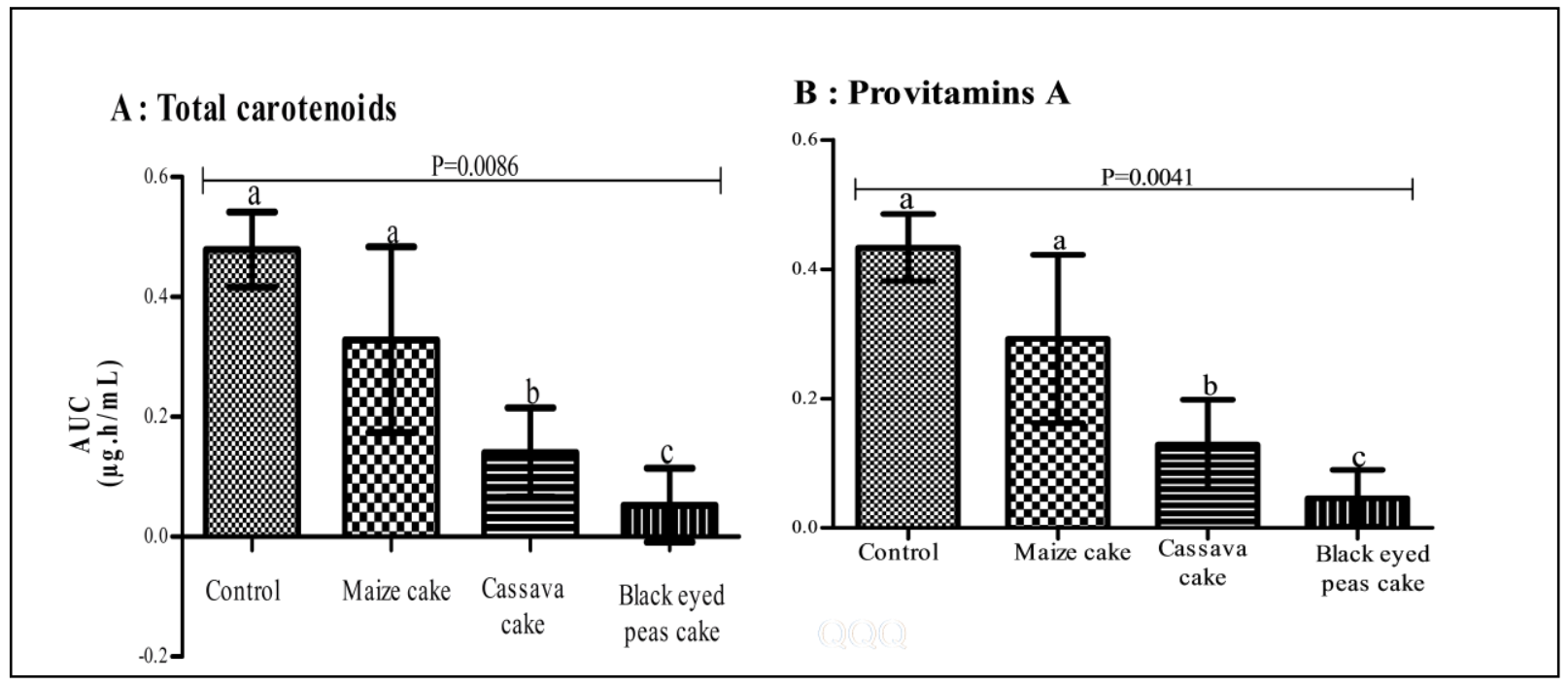

Figure 3. AUC of total carotenoids (A) and provitamins A (B) present in CPO

Note. Vertical bar represented standard deviation. For each parameter, values superscripted with the same letter are not significantly different at $\mathrm{P}<0.05$. 
Changes in blood levels of CPO carotenoids, provitamins A and non provitamins A (lycopene) according to time and type of meal (Table 5) confirm the previous observations. Blood carotenoids levels change significantly for control meal and for maize cake in contrary of cassava and black eyed peas cake. Sure enough, we observed for control meal a significant increase between 0 to 2 hours and a diminution between 2 to 6 hours. For maize cake, this concentration significantly increased from 0 to 6 hours. Cassava and black eyed peas cakes showed a slight augmentation between 0 and 4 hours and a diminution between 4 and 6 hours.

As already noted for carotenoids, blood levels of provitamins A change significantly for control meal and for maize cake and not for cassava and black eyed peas cakes. In fact, for control meal a significant increase between 0 and 2 hours and a decrease between 2 and 6 hours were found. From 0 to 6 hours, increasing in levels of blood provitamins A was significant for maize cake and not significant for cassava and black eyed peas cakes.

Table 5. Changes in blood levels of carotenoids, provitamins A and non-provitamins A analysed present in CPO according to the time and to the meal

\begin{tabular}{|c|c|c|c|c|c|}
\hline & \multicolumn{4}{|c|}{ TIME AFTER CONSUMPTION OF MEAL (hour) } & \multirow[t]{2}{*}{$\mathbf{P}$} \\
\hline & $\mathbf{0}$ & 2 & 4 & 6 & \\
\hline \multicolumn{6}{|l|}{ TOTAL CAROTENOIDS $(\mu \mathrm{g} / \mathrm{ml})$} \\
\hline Control meal (yellow sauce) & $0.663 \pm 0.272^{\mathrm{a}}$ & $0.814 \pm 0.337^{\mathrm{b}}$ & $0.735 \pm 0.305^{\mathrm{c}}$ & $0.692 \pm 0.298^{\mathrm{a}, \mathrm{c}}$ & $<0.0001$ \\
\hline \multicolumn{6}{|l|}{ Test meals } \\
\hline Maize cake & $0.579 \pm 0.213^{\mathrm{a}}$ & $0.606 \pm 0.246^{\mathrm{a}, \mathrm{b}}$ & $0.660 \pm 0.361^{\mathrm{a}, \mathrm{b}}$ & $0.690 \pm 0.272^{\mathrm{b}}$ & 0.0062 \\
\hline Cassava cake & $0.630 \pm 0.273^{\mathrm{a}}$ & $0.644 \pm 0.265^{\mathrm{a}}$ & $0.672 \pm 0.372^{\mathrm{a}}$ & $0.656 \pm 0.293^{\mathrm{a}}$ & $\mathrm{ns}$ \\
\hline Black eyed peas cake & $0.780 \pm 0.338^{\mathrm{a}}$ & $0.788 \pm 0.289^{\mathrm{a}}$ & $0.792 \pm 0.333^{\mathrm{a}}$ & $0.791 \pm 0.330^{\mathrm{a}}$ & $\mathrm{ns}$ \\
\hline \multicolumn{6}{|l|}{ PROVITAMINS A $(\mu \mathrm{g} / \mathrm{ml})$} \\
\hline Control meal (yellow sauce) & $0.558 \pm 0.252^{\mathrm{a}}$ & $0.695 \pm 0.298^{\mathrm{b}}$ & $0.624 \pm 0.276^{\mathrm{c}}$ & $0.585 \pm 0.276^{\mathrm{a}, \mathrm{c}}$ & $<0.0001$ \\
\hline \multicolumn{6}{|l|}{ Test meals } \\
\hline Maize cake & $0.489 \pm 0.192^{\mathrm{a}}$ & $0.512 \pm 0.218^{\mathrm{a}}$ & $0.562 \pm 0.318^{\mathrm{a}, \mathrm{b}}$ & $0.588 \pm 0.245^{\mathrm{b}}$ & 0.0035 \\
\hline Cassava cake & $0.535 \pm 0.262^{\mathrm{a}}$ & $0.547 \pm 0.254^{\mathrm{a}}$ & $0.573 \pm 0.346^{\mathrm{a}}$ & $0.574 \pm 0.281^{\mathrm{a}}$ & $\mathrm{ns}$ \\
\hline Black eyed peas cake & $0.656 \pm 0.310^{\mathrm{a}}$ & $0.663 \pm 0.268^{a}$ & $0.666 \pm 0.308^{\mathrm{a}}$ & $0.667 \pm 0.305^{\mathrm{a}}$ & $\mathrm{ns}$ \\
\hline \multicolumn{6}{|l|}{ NON PROVITAMINS A $(\mu \mathrm{g} / \mathrm{ml})$} \\
\hline Control meal (yellow sauce) & $0.105 \pm 0.025^{\mathrm{a}}$ & $0.120 \pm 0.032^{\mathrm{b}}$ & $0.111 \pm 0.035^{\mathrm{a}, \mathrm{c}}$ & $0.108 \pm 0.026^{\mathrm{c}}$ & $<0.0001$ \\
\hline \multicolumn{6}{|l|}{ Test meals } \\
\hline Maize cake & $0.090 \pm 0.027^{\mathrm{a}}$ & $0.094 \pm 0.033^{\mathrm{a}}$ & $0.098 \pm 0.050^{\mathrm{a}}$ & $0.101 \pm 0.034^{\mathrm{a}}$ & $\mathrm{ns}$ \\
\hline Cassava cake & $0.095 \pm 0.025^{\mathrm{a}}$ & $0.096 \pm 0.024^{\mathrm{a}}$ & $0.099 \pm 0.034^{\mathrm{a}}$ & $0.095 \pm 0.030^{\mathrm{a}}$ & $\mathrm{ns}$ \\
\hline Black eyed peas cake & $0.131 \pm 0.034^{\mathrm{a}}$ & $0.135 \pm 0.033^{\mathrm{a}}$ & $0.136 \pm 0.039^{\mathrm{a}}$ & $0.126 \pm 0.032^{\mathrm{a}}$ & $\mathrm{ns}$ \\
\hline
\end{tabular}

The values are expressed as mean \pm standard deviation. For each parameter and for given meal, the values of the same line superscripted with the same letter are not significantly different at $\mathrm{P}<0.05$

ns: No significant difference at $\mathrm{P}<0.05$

Therefore, increase of blood levels of total carotenoids and provitamins A (Table 4) is linked to CPO carotenoids. In fact, figure 4 which gives the AUC of carotenoids (Figure 4A) and provitamins A (Figure 4B) present and absent in CPO shows that with exception of black eyed peas cake for others meals, the AUC of total carotenoids (respectively for provitamins A) and for those present in CPO are positive. On the contrary, that of carotenoids (respectively for provitamins A) absent is negative regardless to what the meal consists of. 
A : Total carotenoids

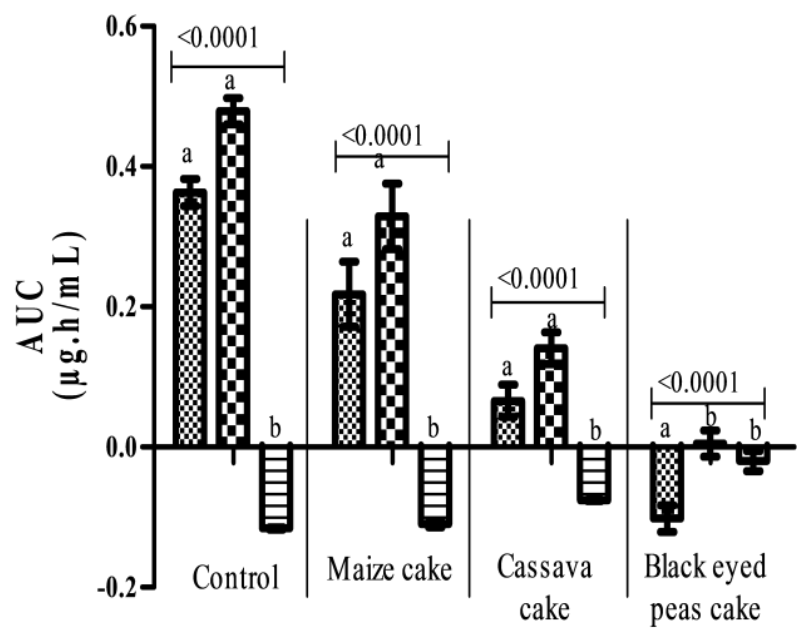

B : Provitamins A

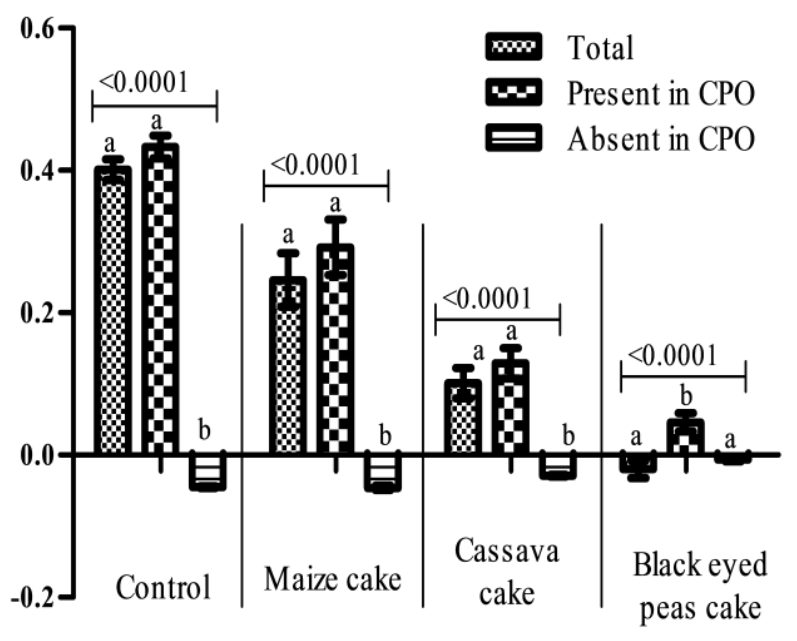

Figure 4. AUC of total carotenoids (A) and provitamins A (B) present and absent in CPO for each meal

Note. Vertical bar represented standard deviation. For each parameter and for given meal, the values superscripted with the same letter are not significantly different at $\mathrm{P}<0.05$.

\subsection{Effect of Studied Meals Ingestion on Others Blood Parameters}

Table 6 shows changes in blood levels of retinol, $\alpha$-tocopherol and triglycerides according to the type of meal consumed and the time after ingestion.

Table 6. Changes in blood levels of retinol, $\alpha$-tocopherol and triglycerides according to meal as a function of time

\begin{tabular}{|c|c|c|c|c|c|}
\hline & \multicolumn{4}{|c|}{ TIME AFTER CONSUMPTION OF MEAL (hour) } & \multirow[b]{2}{*}{$\mathbf{P}$} \\
\hline & $\mathbf{0}$ & 2 & 4 & 6 & \\
\hline \multicolumn{6}{|l|}{ RETINOL $(\mu \mathrm{g} / \mathrm{ml})$} \\
\hline Control meal (yellow sauce) & $0.259 \pm 0.036^{\mathrm{a}}$ & $0.266 \pm 0.035^{\mathrm{a}}$ & $0.269 \pm 0.050^{\mathrm{a}}$ & $0.267 \pm 0.045^{\mathrm{a}}$ & $\mathrm{ns}$ \\
\hline \multicolumn{6}{|l|}{ Test meals } \\
\hline Maize cake & $0.267 \pm 0.018^{\mathrm{a}}$ & $0.282 \pm 0.026^{\mathrm{a}}$ & $0.290 \pm 0.067^{\mathrm{a}}$ & $0.297 \pm 0.051^{\mathrm{a}}$ & $\mathrm{ns}$ \\
\hline Cassava cake & $0.244 \pm 0.055^{\mathrm{a}}$ & $0.282 \pm 0.026^{\mathrm{a}}$ & $0.248 \pm 0.059^{\mathrm{a}}$ & $0.252 \pm 0.078^{\mathrm{a}}$ & Ns \\
\hline Black eyed peas cake & $0.266 \pm 0.048^{\mathrm{a}}$ & $0.274 \pm 0.044^{\mathrm{a}}$ & $0.278 \pm 0.054^{\mathrm{a}}$ & $0.260 \pm 0.036^{\mathrm{a}}$ & Ns \\
\hline \multicolumn{6}{|l|}{$\alpha$-TOCOPHEROL $(\mu \mathrm{g} / \mathrm{mL})$} \\
\hline Control meal (yellow sauce) & $4.86 \pm 0.58^{\mathrm{a}}$ & $6.27 \pm 0.57^{\mathrm{b}}$ & $5.48 \pm 0.60^{\mathrm{c}}$ & $5.21 \pm 0.83^{\mathrm{a}, \mathrm{c}}$ & $<0.0001$ \\
\hline \multicolumn{6}{|l|}{ Test meals } \\
\hline Maize cake & $4.68 \pm 0.86^{\mathrm{a}}$ & $4.86 \pm 0.85^{\mathrm{a}}$ & $4.98 \pm 0.54^{\mathrm{a}}$ & $5.04 \pm 0.84^{\mathrm{a}}$ & Ns \\
\hline Cassava cake & $4.64 \pm 0.91^{\mathrm{a}}$ & $4.70 \pm 0.85^{\mathrm{a}}$ & $4.70 \pm 0.87^{\mathrm{a}}$ & $4.89 \pm 1.91^{\mathrm{a}}$ & Ns \\
\hline Black eyed peas cake & $5.20 \pm 0.76^{\mathrm{a}}$ & $5.39 \pm 0.79^{\mathrm{a}}$ & $5.37 \pm 0.75^{\mathrm{a}}$ & $5.23 \pm 0.60^{\mathrm{a}}$ & Ns \\
\hline \multicolumn{6}{|l|}{ TRIGLYCERIDES (mg/dL) } \\
\hline Control meal (yellow sauce) & $77.63 \pm 6.63^{\mathrm{a}}$ & $82.31 \pm 5.27^{\mathrm{b}}$ & $81.12 \pm 6.02^{\mathrm{b}}$ & $79.89 \pm 5.04^{\mathrm{a}, \mathrm{b}}$ & 0.031 \\
\hline \multicolumn{6}{|l|}{ Test meals } \\
\hline Maize cake & $77.31 \pm 7.14^{\mathrm{a}}$ & $78.33 \pm 6.91^{\mathrm{a}}$ & $79.49 \pm 8.69^{\mathrm{a}}$ & $82.18 \pm 7.58^{\mathrm{a}}$ & Ns \\
\hline Cassava cake & $76.85 \pm 11.16^{\mathrm{a}}$ & $77.23 \pm 11.12^{\mathrm{a}}$ & $78.29 \pm 10.58^{\mathrm{a}}$ & $78.40 \pm 10.96^{\mathrm{a}}$ & Ns \\
\hline Black eyed peas cake & $78.72 \pm 4.90^{\mathrm{a}}$ & $77.62 \pm 6.22^{\mathrm{a}}$ & $78.90 \pm 5.75^{\mathrm{a}}$ & $79.96 \pm 6.41^{\mathrm{a}}$ & Ns \\
\hline
\end{tabular}

The values are expressed as mean \pm standard deviation. For each parameter and for given meal, the values of the same line superscripted with the same letter are not significantly different at $\mathrm{P}<0.05$.

ns: No significant difference at $\mathrm{P}<0.05$

Retinol blood levels did not change significantly after consumption of either test or control meals although one noted a slight increase (Table 6). This finding is comforted by figure 5 which shows that AUC of blood retinol is positive whatever the food is. Moreover, contrary to provitamins A (Figure 3B), there was no significant difference among meals. In fact, one noted an AUC of $0.043 \pm 0.016 \mu \mathrm{g} . \mathrm{h} / \mathrm{ml}$ for control meal, $0.044 \pm 0.027$ 
$\mu \mathrm{g} . \mathrm{h} / \mathrm{ml}$ for maize cake, $0.043 \pm 0.028 \mu \mathrm{g} . \mathrm{h} / \mathrm{ml}$ for cassava cake and of $0.049 \pm 0.006 \mu \mathrm{g} . \mathrm{h} / \mathrm{ml}$ for black eyed peas cake. The slight increase in blood retinol could be attributed to the increase of provitamins A brought by CPO (Figure 3B). A positive correlation although not significant was observed between AUC of retinol and AUC of CPO provitamins A.

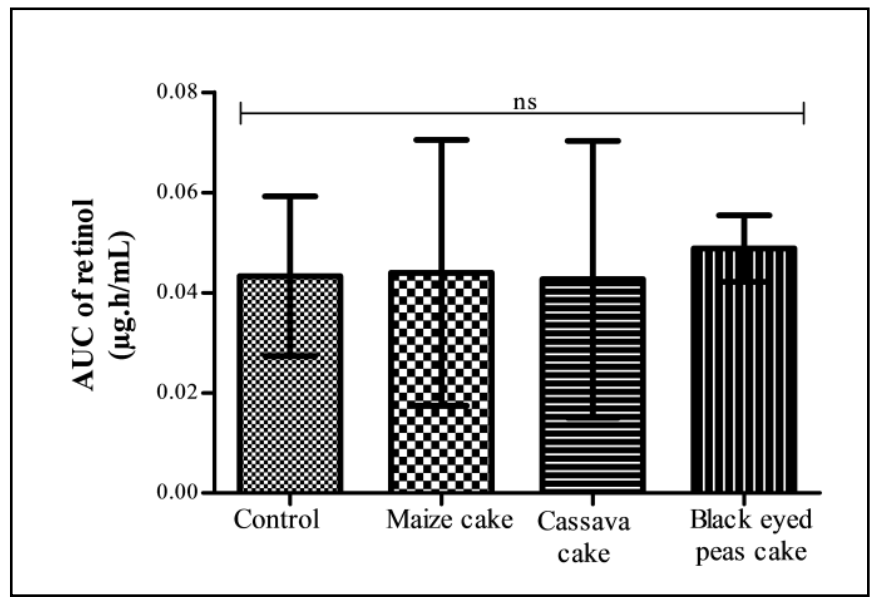

Figure 5. AUC of retinol

Note. Vertical bar represented standard deviation. ns: No significant difference at $\mathrm{P}<0.05$.

Alpha-tocopherol blood levels only increased significantly $(\mathrm{P}<0.0001)$ after control meal ingestion (Table 6). In fact, control meal with an AUC of $4.376 \pm 0.448 \mu \mathrm{g} . \mathrm{h} / \mathrm{ml}$ led to an absorption higher than that obtained with test meals. Maize cake had the highest AUC of $1.484 \pm 0.836 \mu \mathrm{g} . \mathrm{h} / \mathrm{ml}$ (34\% of control meal's AUC) followed by black eyed peas cake $(0.761 \pm 0.234 \mu \mathrm{g} . \mathrm{h} / \mathrm{ml})$ and by cassava cake with $0.477 \pm 0.321 \mu \mathrm{g} . \mathrm{h} / \mathrm{ml}$.

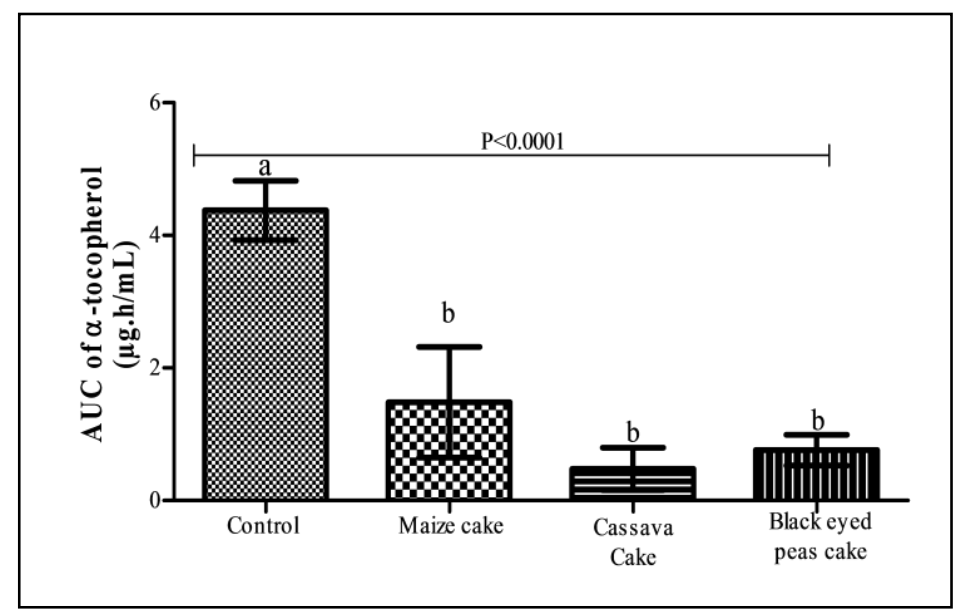

Figure 6. AUC of $\alpha$-tocopherol

Note. Vertical bar represented standard deviation. Values superscripted with the same letter are not significantly different at $\mathrm{P}<0.05$.

Likewise, triglycerides blood levels only increased significantly $(\mathrm{P}<0.0001)$ after control meal ingestion (Table 6). As observed with CPO carotenoids and $\alpha$-tocopherol, AUC of triglycerides (Figure 7) varies significantly $(\mathrm{P}=0.0126)$. Control meal had the biggest AUC $(16.430 \pm 2.202 \mathrm{mg} . \mathrm{h} / \mathrm{dl})$ followed by maize cake $(11.240 \pm 6.513 \mathrm{mg} . \mathrm{h} / \mathrm{dl})$, cassava $(5.188 \pm 1.271 \mathrm{mg} . \mathrm{h} / \mathrm{dl})$ and black eyed peas cakes $(-0.569 \pm 2.767 \mathrm{mg} . \mathrm{h} / \mathrm{dl})$. 


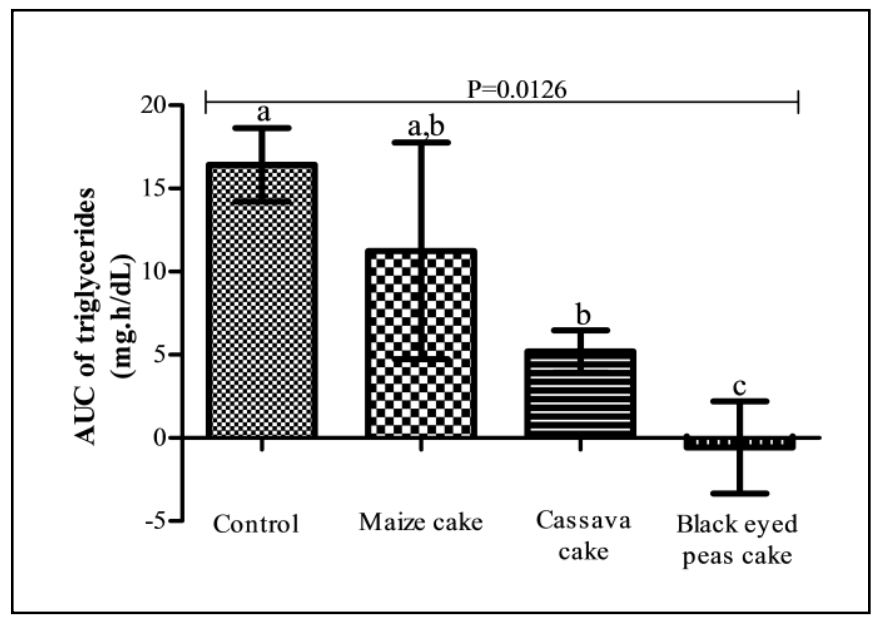

Figure 7. AUC of triglycerides

Note. Vertical bar represented standard deviation. Values superscripted with the same letter are not significantly different at $\mathrm{P}<0.05$.

\section{Discussion}

The objective of this study was to evaluate the influence of CPO containing foodstuff on absorption of carotenoids. Carotenoids contents, proximate and mineral composition of meals used ('yellow sauce', maize, cassava and black eyed peas cakes) were first assessed and the results were in agreement with those reported by Sharma et al. (2007), Kana, Fotso, Gouado, Tetanye, and Amvam (2008), Fokou et al. (2009), Kouebou et al. (2013) and Ponka et al. (2016). Anthropometric and blood parameters of participants before each intervention showed that values of BMI, blood pressure and blood concentration of triglycerides were within their normal ranges. During the first five days before the day of intervention, participants had to eat as usual but carotenoids containing food were not included in diets. Blood retinol was normal and this could be explained by the following reasons: during the test period, eating food with preformed vitamin A was not forbidden; moreover, five days of withdrawal before the intervention are not enough to lead to a significant decrease of retinol in blood supplied from hepatic source. Also, blood levels of carotenoids (lutein, zeaxanthin, $\beta$-cryptoxanthin, $\beta$-carotene, $\alpha$-carotene, lycopene) were found not to be significantly different from values obtained in others studies based on healthy subjects as mentioned earlier. Blood carotenoids levels didn't decrease during the withdrawal period. This could be explained by the residual amount of this compound present in the body before the experimental period. Thus, during the five days of withdrawal, stored carotenoids are mobilized to prevent deficiency. On the contrary, blood levels of $\alpha$-tocopherol were lower than the normal value. This could be due to an inadequate intake of $\alpha$-tocopherol during the withdrawing five days especially since food sources of $\alpha$-tocopherol are generally the same as those of carotenoids. So $\alpha$-tocopherol statute of participants were good before they entered into the withdrawing period.

Our study confirms that CPO carotenoids are bioavailable. In fact, for both control and test meals there was an increase of carotenoids in blood after consumption of each meal. This increase could be attributed to CPO. Our study revealed no increase of blood retinol after consumption of test or control meals but results showed that CPO could be used to fight against VAD because of its contents in provitamins A. In fact, one noticed for carotenoids present in CPO a significant augmentation as well as for provitamins A and for non-provitamins A. We found that mixing other foods with CPO results in decreasing carotenoids bioavailability. This would be a consequence of meal consistency modification which affects digestion. For example, solid foods delay digestion compared to semi-solid or liquid foods. Besides, introduction of another food in CPO can release other nutrients or anti-nutritionals factors which could modify carotenoids bioavailability by interfering with: (1) their transfer from meal bolus to micelles; (2) intestinal absorption of micelles; (3) intra-enterocytic transport of carotenoids; (4) integration of carotenoids in chylomicrons; (5) or their secretion in general circulation (Borel et al., 2005). Besides, it is known that $1 \mu \mathrm{g}$ of retinol corresponds to $2 \mu \mathrm{g}$ of $\beta$-carotene (and $4 \mu \mathrm{g}$ of others provitamins A) from oils against $12 \mu \mathrm{g}$ of $\beta$-carotene (respectively $24 \mu \mathrm{g}$ of others provitamins $\mathrm{A}$ ) from others sources (Betty, 2012).

Furthermore, this study showed that the bioavailability of CPO carotenoids significantly varies with the foodstuff to which oil is associated. In fact, for the three test meals, we noticed that carotenoids bioavailability was higher 
for maize cake (cereal) compared to cassava (tuber) and black eyed peas (leguminous) cakes. It was slightly higher for cassava cake compared to black eyed peas cake. These differences in bioavailability according to foodstuff associated to CPO could be explained by the difference in composition of these foods. It is known that some lipids and dietary fibers can affect carotenoids metabolism (Borel et al., 2005; Hammond \& Renzi, 2013).

It is also known that carotenoids are often in competition with their own absorption. This depends on the nature and quantity of carotenoids present in food (Eroglu \& Harrison, 2013). But, carotenoids composition of the test and control meals used in this study could not explain the difference observed because meals contained the same quantity of carotenoids $(10 \mathrm{mg}$ ) per eaten portion and came from the same source which is CPO.

Lipids content of the test meals could not explain either the difference in bioavailability, the amount of all meals consumed provided almost the same quantity of lipids $(29.45,25.88$ and $28.01 \mathrm{~g}$ respectively for maize, cassava and black eyed peas cakes). These quantities are greater than the minimal quantity of lipids required in a meal (3-5 g) for a good assimilation of carotenoids (Yonekura \& Nagao, 2007; Goltz et al., 2012; Hammond \& Renzi, 2013).

Dietary fibers affect lipids digestion in human and as a matter of fact, that of carotenoids. Their non-digestible character in human digestive prevents production of micelles by inhibiting digestive lipases activity and/or by binding to bile acids or to phospholipids. Fibers also increase intestinal content, viscosity and volume thereby slowing processes of diffusion of micelles on the absorbent surface of enterocytes (Yonekura \& Nagao, 2007; Eroglu \& Harrison, 2013). Besides, Riedl et al. (1999) confirmed that dietary fibers decrease carotenoids absorption in human. Differences in carotenoids bioavailability observed in our study could be explained by dietary fibers content of studied meals. We found that carotenoids bioavailability is inversely proportional to the dietary fibers content of meal. For example, maize cake which showed the highest bioavailability had the lowest quantity of dietary fibers (20.98 g per eaten portion) whereas black eyed peas cake which had the lowest bioavailability contained the highest quantity of dietary fibers (27.79 g per eaten portion). Nature and distribution of dietary fibers in the meals could also explain the difference in bioavailability. In fact, Riedl et al. (1999) reported that effect of dietary fibers on carotenoids absorption varies according to the type of fiber.

It had also been found that divalent cations decrease the formation of micelles and absorption of carotenoids by Caco-2 cells, Biehler et al. (2011). Divalent cations may react with free fatty acids (forming irreversible soaps) and with bile acids thereby reducing formation of micelles. It is known that carotenoids absorption depends not only to the quantity of micelles formed, but also to the concentration of carotenoids in these micelles. By preventing the formation of micelles and the transfer of carotenoids to micelles, divalent cations affect intestinal absorption of carotenoids. This could also explain the difference of bioavailability observed in meals of this study because different divalent cations are present. Black eyed peas cake which had highest quantity of divalent cations (488.58 mg per eaten portion) showed the lowest bioavailability while maize cake which showed the highest bioavailability contained the lowest quantity of divalent cations $(225.30 \mathrm{mg})$ per eaten portion. The ratio of quantity of proteins/quantity of digestive carbohydrates per eaten portion is higher for black eyed peas cake (0.3) compared to maize (0.13) and cassava (0.02) cakes. Digestion of proteins being slower than that of digestive carbohydrates (Whitney \& Rolfes, 2008), can delay intestinal digestion in general and therefore that of carotenoids. This could partly explain why carotenoids bioavailability was loweer in black eyed peas cake compared to others meals.

Blood retinol did not vary significantly after consumption of control meal as well as test meals. This result does not mean that provitamins A from CPO didn't affect vitamin A status of participants. Provitamins A could be absorbed and converted into retinol. Later on, this retinol is transformed into its different metabolites (retinal, retinoic acid) for metabolic uses (Edem, 2009). Unfortunately, the method used in this study to measure blood vitamin A (HPLC) detects only retinol and not its metabolites. Participants in the study had normal blood levels of retinol at the start of each intervention. It is admitted that the conversion of provitamins A into vitamin A is regulated by individual vitamin A statute. This conversion is activated when the blood concentration of retinol decreases and is inhibited when it is normal or high in order to avoid hypervitaminosis A which is dangerous for organism (Reboul, 2013). This could partly explain our result because for CPO carotenoids, changes in blood levels of provitamins A were not significantly different to that of non-provitamins A. Provitamins A are converted into vitamin A and their blood levels should significantly decrease more rapidly than those of non provitamins A (Tang, 2010). Blood levels of $\beta$-cryptoxanthin (provitamin A absent in CPO) having significantly decreased time wise, we cannot conclude that there was no conversion of provitamins A into vitamin A. It could have occurred, but at slow speed. Given that among blood carotenoids analysed, for those contained in CPO and so in studied meals, the ratio of provitamins $\mathrm{A}$ ( $\alpha$ - and $\beta$-carotene) on non-provitamins $\mathrm{A}$ (lycopene) is about 65 so widely in favour of provitamins A. So, one could expect the absorption of provitamins A to be significantly 
higher than that of non-provitamins A. Given that blood retinol of participants was normal at the start of intervention, provitamins A absorption could have been inhibited. This is why changes of non-provitamins A was not significantly different to that of provitamins A for both control and tests meals. It is known that intestinal absorption of provitamins A is inhibited when blood concentration of retinol is normal or high and is activated when it is low (Borel et al., 2005).

For CPO $\alpha$-tocopherol, carotenoids, changes in blood levels were higher for control meal compared to test meals. For test meals, increase was higher in maize cake compared to cassava and black eyed peas cakes. Tocopherol and carotenoids lipid-soluble compounds almost have the same digestion process. So, difference noted in blood response among studies meals could be explained by the same reasons as carotenoids (Borel et al., 2005; Iqbal \& Hussain, 2009). Changes in blood $\alpha$-tocopherol were higher than that of CPO carotenoids for control meal and test meals. This could be explained by the fact that on contrary of carotenoids, at the start of interventions, participants had blood $\alpha$-tocopherol lower than normal. If $\alpha$-tocopherol present in our meals comes exclusively from CPO, their amount in these meals would be higher than that of carotenoids. Consequently, absorption of $\alpha$-tocopherol would be more stimulated than that of carotenoids.

Blood triglycerides levels varied significantly only for control meal. This variation happened directly after consumption. Slight change with test meals happened only from 2 hours after consumption. If absorption of triglycerides was also faster for control meal and not for test meals, it is probably because of their respective compositions. In fact, control meal contained exclusively lipids as sources of energy whereas test meals contained proteins and digestives carbohydrates. The participants absolutely needed energy source given that they fasted at least 12 hours before each intervention. In control meal, the only source of energy is triglycerides on contrary to test meals which also contained carbohydrates which are the best energetic metabolites for living organisms (Whitney \& Rolfes, 2008 ; Iqbal \& Hussain, 2009).

\section{Conclusion}

Consumption of CPO leads to significant increase in blood concentration of carotenoids and particularly provitamins A. Association of another food with CPO decreases bioavailability of carotenoids. The decrease varies significantly according to foodstuff and depends of its composition (dietary fibers, bivalent cations and proteins). It seems to be more important with leguminous, tubers and less important with cereals. Consumption of maize, cassava and black eyed peas cakes doesn't significantly affect in short term blood levels of retinol but leads to an increase of $\alpha$-blood tocopherol.

\section{Conflict of interests}

FJS is shareholder of BioAnalyt GmbH, Germany. All other authors declare no conflict of interests regarding the publication of this paper.

\section{Acknowledgments}

The authors would like to thank BioAnalyt GmbH (Teltow, Germany) for gracefully provided us the photometer (iCheckTM carotene) used for carotenoid analysis of studied meals. We also want to thank all participants and Mr. TCHAMTCHEU ENGA JOEL for their kind contribution to the study. Likewise, we need to express our gratitude to Mr. Jean Pierre ZO'OBO for comments that greatly improved this manuscript.

\section{References}

Aggett, P. J. (2010). Population reference intakes and micronutrient bioavailability: A European perspective. The American Journal of Clinical Nutrition, 91(suppl), 1433S-1437S. https://doi.org/10.3945/ajen.2010.28674C

Betty, J. B. (2012). Evaluating global barriers to the use of red palm oil as an intervention food to prevent vitamin A deficiency. Comprehensive Reviews in Food Science and Food Safety, 11, 221-232. https://doi.org/10.1111/j.1541-4337.2011.00181.x

Biehler, E., Hoffmann, L., Krause, E., \& Bohn, T. (2011). Divalent minerals decrease micellarization and uptake of carotenoids and digestion products into caco-2 cells. Journal of Nutrition, 141, 1769-776. https://doi.org/10.3945/jn.111.143388

Boonsiri, P., Pooart, J., Tangrassameeprasert, R., \& Hongsprabhas, P. (2007). Serum $\beta$-carotene, lycopene and $\alpha$-tocopherol levels of healthy people in northeast Thailand. Asia Pacific Journal of Clinical Nutrition, 16, (Suppl 1), 47-51.

Borel, P., Drai, J., Faure, H., Fayol, V., Galabert, C., Laromiguière, M., \& Le Moël, G. (2005). Recent data on carotenoids absorption and catabolism. Annales de Biologie Clinique, 63, 165-177. 
Choo, Y. M., \& Kalanithi, N. (2014). Research advancements in palm oil nutrition. European Journal of Lipid Science and Technology, 116, 1301-1315. https://doi.org/10.1002/ejlt.201400076

Chuks, K. O., Tarfen, Y. A., Ikechukwu, P. O., Paul, E. M., Benedict, T. S., Uche, K. A., ... Amechi, S. N. (2016). Assessment of mold contamination and physicochemical properties of crude palm oil sold in Jos, Nigeria. Food Science \& Nutrition, published by Wiley Periodicals, Inc. https://doi.org/10.1002/fsn3.393

Dongho D. F. F., Gouado, I., Sameza, M. L., Mouokeu, R. S., Demasse, M. A., Schweigert, F. J., \& Ngono, N. A. (2017). Some factors affecting quality of crude palm oil sold in Douala, Cameroon. Journal of Food Research, 6(1), 50-58. https://doi.org/10.5539/jfr.v6n1p50

Dongho, D. F. F., Ngono, N. A., Demasse, M.A., Schweigert, F., \& Gouado, I. (2014). Effect of heating and of short exposure to sunlight on carotenoids content of crude palm oil. Journal of Food Processing and Technology, 5(4), 314. https://doi.org/10.4172/2157-7110.1000314

Edem, D. O. (2009). Vitamin A: A review. Asian Journal of Clinical Nutrition, 1, 65-82. https://doi.org/10.3923/ajen.2009.65.82

Engle-Stone, R., Nankap, M., Ndjebayi, O. A., \& Kenneth, H. (2014). Simulations based on representative 24-h recall data predict region-specific differences in adequacy of vitamin A intake among Cameroonian women and young children following large-scale fortification of vegetable oil and other potential food vehicles. Journal of Nutrition, 144, 1826-1834. https://doi.org/10.3945/jn.114.195354

Eroglu, A., \& Harrison, E. H. (2013). Carotenoid metabolism in mammals, including man: formation, occurrence, and function of apocarotenoids. Journal of Lipid Research, 54, 1719-1730. https://doi.org/10.1194/jlr.R039537

FAO (2012). West African compostion table. Food Agriculture Organization of the United Nation, Rome.

Fokou, E., Ponka, R., Tchinda, D. P. H., Domguia, K. H. B., Tchouba, L. B., Achu, M. B. \& Fotso, M. (2009). Methods of preparation and nutritive value of some dishes consumed in the west region of Cameroon. Pakistan Journal of Nutrition, 8, 1190-1195. https://doi.org/10.3923/pjn.2009.1190.1195

Goltz, S. R., Campbell, W. W., Chitchumroonchokchai, C., Failla, M. L., \& Ferruzzi, M. G. (2012). Meal triacylglycerol profile modulates postprandial absorption of carotenoids in humans. Molecular Nutrition and Food Research, 56(6), 866-877. https://doi.org/10.1002/mnfr.201100687

Gouado, I., Ejoh, A. R., Kenne, M., NNdifor, F., \& Tchouanguep, F. B. (2005). Serum concentration of vitamin A and E, and lipid in rural population of North Cameroon. Annal of Nutrition and Metabolism, 49, 26-32. https://doi.org/10.1159/000084174

Grant, M. (2015). A food systems approach for food and nutrition security. Sight and Life, 29(1): 87-90.

Gretchen, A. S., James, E. B., Quentin, H., Yuan, L., Luz, M. D. R., Lisa, R., ... Majid, E. (2015). Trends and mortality effects of vitamin A deficiency in children in 138 low-income and middle-income countries between 1991 and 2013: a pooled analysis of population-based surveys. The Lancet Global Health, 3, 528-536. https://doi.org/10.1016/S2214-109X(15)00039-X

Guangwen, T. (2013). Using plant foods rich in $\beta$-carotene to combat vitamin a deficiency. Sight and Life Magasine, 27(1), 20-28.

Hammond, B. R., \& Renzi L. M. (2013). Carotenoid. Advances in Nutrition, 4, 474-476. https://doi.org/10.3945/an.113.004028

Iqbal, J., \& Hussain, M. M. (2009). Intestinal lipid absorption. American Journal of Physiology-Endocrinology and Metabolism, 296, 1183-1194. https://doi.org/10.1152/ajpendo.90899.2008

Kana, S. M. M., Fotso, M., Gouado, I., Tetanye, E., \& Amvam Z. P. H. (2008). Nutritional survey, staple foods composition and the uses of savoury condiments in Douala, Cameroon. African Journal of Biotechnology, 7 , 1339-1343. https://doi.org/10.5897/AJB07.844

Kiokias, S., Proestos, C., \& Varzakas T. (2016). A review of the structure, biosynthesis, absorption of carotenoids-analysis and properties of their common natural extracts. Current Research in Nutrition and Food Science, 4(1), 25-37. https://doi.org/10.12944/CRNFSJ.4.Special-Issue1.03

Kouebou, C. P, Achu, M., Nzali, S., Chelea, M., Bonglaisin, J., Kamda, A., ... Kana, S. M. M. (2013). A review of composition studies of Cameroon traditional dishes: Macronutrients and minerals. Food Chemistry, 140, 483-494. https://doi.org/10.1016/j.foodchem.2013.01.003 
Macias, C., \& Schweigert, F. J. (2001). Changes in the concentration of carotenoids, vitamin A, alpha-tocopherol and total lipids in human milk throughout early lactation. Annals of Nutritition and Metabolism, 45, 82-85. https://doi.org/10.1159/000046711

Manorama, K. (2014). Potential use of red palm oil in combating vitamin a deficiency in India. Indian Journal of Commity Health, 26(Suppl S1), 45-53.

Ministry of Public Health in Cameroon, Helen Keller International Cameroon, UNICEF (2011). National survey of micronutrient status and consumption of fortifiable foods. Yaounde (Cameroon): Helen Keller International Cameroon.

Molldrem, K. L., Li, J., Simon, P. W., \& Tanumihardjo, S. A. (2004). Lutein and $\beta$-carotene from lutein-containing yellow carrots are bioavailable in humans. The American Journal of Clinical Nutrition, 80, 131-136.

Mukherjee, S., \& Mitra, A. (2009). Health effects of palm oil. Journal of Human Ecology, 26, 197-203.

Odia, O. J., Ofori, S., \& Maduk, O. (2015). Palm oil and the heart: A review. World Journal of Cardiology, 7 , 144-149. https://doi.org/10.4330/wjc.v7.i3.144

Olaf, S., Silke, D. S., Annett, M., Cornelia, J., Claus-Dieter, L., Kalanithi, N., ... Marcus, A. M. (2015). Supplementation with red palm oil increases $\beta$-carotene and vitamin A blood levels in patients with cystic fibrosis. Mediators Inflamm., ID 817127, https://doi.org/10.1155/2015/817127.

Owoyele, B. V., \& Owolabi, G. O. (2014). Traditionnal oil palm (Elaeis guineesis jacq.) and its medicinal uses: A review. Tang Humanitas medicine, https://doi.org/10.5667/tang.2014.0004.

Pignitter, M., \& Somoza, V. (2012). Are vegetable oils always a reliable source of vitamin A? A critical evaluation of analytical methods for the measurement of oxidative rancidity. Sight and Life Magasine, 26(1), 18-27.

Ponka, R., Fokou, E., Beaucher, E., Piot M., \& Gaucheron, F. (2016). Nutrient content of some Cameroonian traditional dishes and their potential contribution to dietary reference intakes. Food Science and Nutrition, 4, 696-705. https://doi.org/10.1002/fsn3.334.

Reboul, E., Richelle, M., Perrot, E., Desmoulins-Malezet, C., Pirisi, V., \& Borel, P. (2006). Bioaccessibility of carotenoids and vitamin E from their main dietary sources. Journal of Agricultural Food Chemistry, 54, 8749-8755. https://doi.org/10.1021/jf061818s

Ribaya-Mercado, J. D., Maramag, C. C., Tengco, L.W., Blumberg, J. B., \& Solon, F.S. (2008). Relationships of body mass index with serum carotenoids, tocopherols and retinol at steady-state and in response to a carotenoids-rich vegetable diet intervention in Filipino schoolchildren. Bioscience Report, 28, 97-106. https://doi.org/10.1042/BSR20070045

Riedl, J., Linseisen, J., Hoffmann, J., \& Wolfram, G. (1999). Some dietary fibres reduce the absorption of carotenoids in women. Journal of Nutrition, 129, 2170-2176.

Roodenburg, A. J. C., Leenen, H., Van Het Hof, K. H., Weststrate, J. A. \& Tijburg, L. B. M. (2000). Amount of fat in the diet affects bioavailability of lutein esters but not of a-carotene, $\beta$-carotene, and vitamin $\mathrm{E}$ in humans. The American Journal of Clinical Nutrition, 71, 1187-1193.

Schweigert, F. J., Klingner, J., Hurtienne, A., \& Zunft, H. J. (2003). Vitamin A, carotenoids and vitamin E plasma concentrations in children from Laos in relation to sex and growth failure. Nutrion Journal, 2:17. https://doi.org/10.1186/1475-2891-2-17

Sharma, S., Mbanya, J. C., Cruickshank, K., Cade, J, Tanya, A. K. N., Cao, X., ... Wong, M. R. K. M. (2007). Nutritional composition of commonly consumed composite dishes from the Central Province of Cameroon. International Journal of Food Science and Nutrition, 58, 475-485. https://doi.org/1.1080/09637840701288454

Souganidis, E., Laillou, A., Leyvraz, \& Moench-Pfanner, R. (2013). A comparison of retinyl palmitate and red palm oil $\beta$-carotene as strategies to address vitamin A deficiency. Nutrients, 5, 3257-3271. https://doi.org/10.3390/nu5083257

Strehl, E., Harris, K. J., Brown, B., Mirtuse, G. M., \& Stanhope, L. (2015). Strategies for mitigating vitamin A deficiency in Mekelle, Ethiopia (April 18, 2015). Graduate Student Research Conference. Paper 4. http://scholarworks.umt.edu/gsrc/2015/oralpres2b/4 
Strobel, M., Tinz, J., \& Biesalski, H. K. (2007). The importance of $\beta$-carotene as a source of vitamin A with special regard to pregnant and breastfeeding women. European Journal of Nutrition, 46(S1), 1-20. https://doi.org/10.1007/s00394-007-1001-z

Valtuena, J., Breidenassel, C., Folle, J., \& González-Gross, M. (2011). Retinol, $\beta$-carotene, $\alpha$-tocopherol and vitamin D status in European adolescents; regional differences and variability: A review. Nutricion Hospitalaria, 26, 280-288. https://doi.org/10.1590/S021-16112011000200006

Whitney, E., \& Rolfes, R. S. (2008). Understanding nutrition, $12^{\text {th }}$ Edition. Thomson Higher Education. 10 Davis Drive. Belmont, CA94002-3098,USA.

WHO (2009). Global prevalence of vitamin A deficiency in populations at risk 1995-2005. WHO global database on vitamin A deficiency. Geneva, World Health Organization.

Yonekura, L, \& Nagao A. (2007). Intestinal absorption of dietary carotenoids. Molecular Nutrition and Food Research, 51, 107-115. https://doi.org/10.1002/mnfr.200600145

Zhu, C., Cai, Y., Gertz, E. R., La Frano, M. R., Burnett, D. J., \& Burri B. J. (2015). Red palm oil-supplemented and biofortified cassava gari increase the carotenoid and retinyl palmitate concentrations of triacylglycerol-rich plasma in women. Nutr. Res., 35, 965-974.

https://doi.org/10.1016/j.nutres.2015.08.003

\section{Copyrights}

Copyright for this article is retained by the author(s), with first publication rights granted to the journal.

This is an open-access article distributed under the terms and conditions of the Creative Commons Attribution license (http://creativecommons.org/licenses/by/4.0/). 